\title{
Elders Decry the Loss of Ubuntu
}

\section{Mishack T Gumbo}

\author{
University of South Africa
}

gumbomt@unisa.ac.za

\section{Doi:10.5901/mjss.2014.v5n10p67}

\begin{abstract}
This paper reports the findings of a study conducted on the issues surrounding ubuntu. It addresses the questions: What is ubuntu? What has happened to ubuntu? Five elders were selected from Akasia in the north of Pretoria and interviewed. Several themes emanating from the findings reveal challenges that ubuntu faces in response to the question of what has happened to ubuntu. The elders' definition of ubuntu places children at the centre, that is, ubuntu is the way children relate to the elderly in terms of respect that they must show. In conclusion I suggest an ubuntu mode in figure 1, which is opposed to the individualism mode in figure 2.
\end{abstract}

Keywords: Ubuntu, communalism, communitarianism, individualism, elders.

\section{Introduction}

In this paper I present the views of elders about ubuntu. It is important to investigate the thinking of elders about ubuntu to add to the existing body of knowledge which seems to fall short of this perspective to some extent. Ubuntu stems from the elders' attempts to teach their children a way of life that is premised on humanism. This strengthens the need to present the elderly perspective as a result. In this paper I entertain the questions: What is ubuntu? What has happened to ubuntu? I deem it important to address these questions, especially from the elders' point of view, due to the colonial attempts to plunder it in South African society. In an attempt to address this question I reflect briefly on these colonial attempts, discuss attempts to revitalise ubuntu, explore the challenges facing ubuntu and present the findings from the interviews with elders. However, before I go deeper into this paper let me clarify the concept of ubuntu and a few related concepts; all of these can illuminate the understanding of the issues raised in the paper.

Ubuntu: Ubuntu is a Bantu characteristic of relationships, and Bantu means people (Muwanga-Zake, 2009). Bantu cover almost a third of sub-Saharan Africa and speak over 400 Bantu (indigenous) languages in South Cameroon, the south-eastern region of Nigeria, Gabon, Equatorial Guinea, Republic of Congo, Democratic Republic of Congo, Rwanda, Burundi, Uganda, Kenya, southern Somalia, Tanzania, Angola, Zambia, Malawi, Mozambique, Zimbabwe, Namibia, Botswana and South Africa (Muwanga-Zake, 2009). This explains the diverse forms in which ubuntu is found in many societies throughout Africa (Muwanga-Zake, 2009). This diversity also implies the diverse expressions of ubuntu in accordance with varying indigenous languages. For instance, motho ke motho ka batho ba bangwe (Tswana) (Mokgoro, 1997); umuntu ngumuntu ngabantu (Zulu) (Mokgoro, 1997; Nyaumwe \& Mkabela, 2007); munhu munhu ngevamwe (Shona) (Nyaumwe \& Mkabela, 2007), which, literally translated, means a person can only be a person through others (Mokgoro, 1997; Nyaumwe \& Mkabela, 2007).

Ubuntu says to community members that the essence of being a human being is seen through a community that cherishes and lives the ideas of ubuntu. "Ubuntu is a communal way of life which deems that society must be run for the sake of all, requiring co-operation as well as sharing and charity" (Broodryk, 2006). Therefore, ubuntu is "an African value system that means humanness or being human, a worldview characterised by such values as caring, sharing, compassion, communalism, communocracy and related predispositions" (Khoza, 2005, p. 269). To this Broodryk (2006, p. 13) adds that ubuntu is the quality of being human and ensures a happy and qualitative human community life in the spirit of family. In this kind of existence, one person's personhood and identity is fulfilled and complemented by the other person's personhood; each person is because the other person is; each person exists because the other person exists (Muwanga-Zake, 2009, p. 5).

To sum up this definition, the values that define ubuntu include: togetherness, brotherhood, equality, caring, sharing, sympathy, empathy, compassion, respect, tolerance, humanness, harmony, redistribution, obedience, happiness, wisdom, communalism, communitarianism, kinship, group solidarity, conformity, human dignity, humanistic 
orientation and collective unity.

Communitarianism: The term communitarianism is derived from the word community. Communitarianism helps with the understanding of ubuntu in the sense that it means any philosophical standpoint that defines a person in the context of social bonds and cultural traditions rather than through individual traits (Mabovula, 2011, p. 38). Ramose (2002) also avers that an African community is an ongoing dynamic association of men and women who have a special commitment to one another and have developed a distinct sense of their common life.

Communalism: According to Khoza (2005, p. 266), communalism is a concept that views humanity in terms of collective existence and inter-subjectivity, which serves as the basis for supportiveness, cooperation, collaboration and solidarity. This builds on Gyekye's definition (in Mabovula, 2011, p. 38), of communalism as a kinship-oriented social order which is informed by an ethic of reciprocity. "This form of communalism signifies the human person as an inherently communal being embedded in a context of social relationships and interdependence, and never as an isolated, atomistic individual" (Mabovula, 2011, p. 38).

The above-defined concepts bring to the centre how a person is viewed by a community. The community defines the person as a person, not some isolated static quality of rationality, will or memory as it seems to be from a western stance. In this sense a definition of a person is expressed in terms of him being a biological relative of a broad family. This family belongingness points to the extended family ties of indigenous communities. We feel the substance of ubuntu when we "flock" together, sing together, share fellowship over a meal, and share and show solidarity and empathy towards one another. Our approach to life is a communalistic rather than individualistic approach. One is a part of a broad network of other people. Practical examples are evident in how African indigenous communities interact and associate in marriage, one is not only married to an individual but into a family; association with others happens through community roles, duties, obligations, responsibilities and neighbourhood. Interdependence solidifies these ties and networks.

\section{Attempts of Colonial Practices to Discredit/Dismantle Ubuntu}

Apartheid has been the most conspicuous attempt by colonial practices in South Africa to destroy anything African or impose westernisation upon Africanism through government institutions and programmes. One sector through which this happened is education. Western ideologies and culture were being hammered into the African child at the expense of African values and culture to ensure the deadness of Africanness and implantation of westernness. The curriculum that the African child received was not remotely related to his/her culture; neither did the content contain a representation of the richness of African indigenous knowledge forms. For example, the history subject used to emphasise the Europeans' history and demeanour by portraying Europeans as masters and Africans as slaves and the conquered people. The South African history component focused more on the Whites' history by way of learning about their arrival, the so-called "great trek" (movement) and pogroms.

Nassbaum (2003) relates the great loss regarding ubuntu brought upon by westernisation, which is visible in the form of westerners' misunderstanding of the great contribution that African values could make towards the world consciousness. This misunderstanding is informed by the inaccessibility of Africa's traditional culture as most of it is oral and lived rather than formally written and communicated in books or journals (which makes it difficult to learn). Moreover, westerners receive negative and limited information through media which include, for example, images of ethnic wars, dictatorships, famine and the predominance of AIDS.

What we learn, then, is the gross stifling of ubuntu that was perpetuated by the apartheid regime as Africans tried to fight for their liberation (Masango, 2006). This situation has led to decrying the loss of ubuntu and the ultimate search and revitalisation thereof at the dawn of democracy (Masango, 2006).

\section{Attempts to Revitalise Ubuntu}

The enactment of democracy that was ushered in by the reconciliatory transformation in South Africa created a platform to restore and promote ubuntu. Mabovula (2011, p. 41) claims in this regard, that in the South African context, ubuntu is seen as a notion with particular resonance in the building of democracy. The country's preparations for democracy were characterised by talks by government officials which produced an Interim National Constitution seen as a tool to advance an ubuntu-based transformation as a response to colonial practices.

Parts of the Constitution's Bill of Rights, such as section 9 (the right to life) and section 15 (the right to human dignity) attest to the commitment to promote ubuntu. Thus, I understand the Bill of Rights as an attempt to give expression to ubuntu values. Mabovula (2011, p. 41) notices that in the 1990s ubuntu received recognition from the Interim Constitution. According to Mabovula (2011, p. 41), the post-preamble to the Interim Constitution (1993) includes 
the following lines:

The adoption of this constitution lays the secure foundation for the people of South Africa and enables them to transcend the divisions and strife of the past, which generated gross violations of human rights, the transgression of humanitarian principles into violent conflicts and a legacy of hatred, fear, guilt and revenge.

Mabovula (2011, p. 41) catches an important claim in the postscript to the Interim Constitution about ubuntu being explicitly mentioned as the source of the underlying values of the new South Africa. At grassroots level, ubuntu as enshrined in the Interim National Constitution was planned to be enacted through (Broodryk, 2006) the following:

- Batho pele (people first) principles to inform the vision and mission of the face of public service;

- various government departments like the Department of Social Development, Education, Safety and Security;

- the mission of the National Library;

- the business philosophy of various companies in the private sector;

- tertiary institutions under disciplines like Education, Welfare, Philosophy, Philosophy of Education, Anthropology, Sociology, Criminology, Public Administration, Law and Commercial Studies;

- National Education in schools as part of the subject Guidance;

- hearings of the post-apartheid Truth and Reconciliation Commission;

- national youth development programmes and strategies like the June 16 youth rally; and

- the National Moral Regeneration Movement of the Republic of South Africa.

Note that this far I have referred to the Interim National Constitution as encapsulating ubuntu. The question arises, however, what about the final Constitution? A great deal about ubuntu still remains in the final Constitution in the form of the Bill of Rights. I notice, with regret, the grievous mistake about the omission of the term ubuntu itself. This leaves me distraught and with a feeling that ubuntu principles have nothing to hang onto! This omission signals a lackadaisical attitude about the enactment of ubuntu, and many problems that seem to plunder society like unbridled floods. It is because of this that I ask in this article: What has happened to ubuntu? The presented perspective about challenges that surround ubuntu allows me to now focus on these challenges.

\section{Challenges and Deeper Understandings of Ubuntu}

Challenges facing ubuntu surface from a few areas that receive attention in this section. The first challenge has to do with governance which sources its roots mainly from the western system of government. In this regard I claim that attempts by western colonisation to erode ubuntu have left their marks in satellites that manifest in terms of greedy and corrupt government officials. Even African governments have inherited western aggrandisement and moved away from the community-based government systems that are informed by the philosophy of ubuntu. Worse even is the attitude of disregard for the elders who are viewed as illiterate or ignorant.

It would be much appreciated if every government programme introduced in communities could have as part of its goals, ways to promote and work together with existing community structures which promote the practice of ubuntu. Unfortunately the introduction of political figures who seem to take over from chiefs has the whole community now diverting their attention from elders to these politicians in the hope of being better looked after. While the commitment by government is to provide services to communities, care should be taken not to raise political figures above community leaders. A proper partnership between the tribal government system and state-based government system has the potential to recognise the tribal authorities' contribution in upholding the ideals of ubuntu, which can mitigate crime.

Currently, it would seem that self-enriching and corrupt schemes occupy the lives of government officials at all levels of government. This further undermines service delivery efforts and Batho pele (people first) principles which are the terrain of ubuntu. Mabovula (2011) cites Waliggo who observes that the contemporary African society does not take the current economic immorality and crimes which involve fraud, embezzlement of public funds, corruption and abuse of office, seriously. Waliggo argues that instead of exposing crimes committed against the state, many people tend to praise and protect their own relatives and friends who perpetrate economic crimes against the state to uplift their own areas and to enrich their people. The African National Congress elections meeting in Mangaung towards the end of 2012 made a pledge to establish a committee that would expose acts of corruption by its members, who are in office, crack a whip about this and introduce a "shame-them" system, which publishes the names of corrupt officials. I wonder if this move will be punitive at all - it appears that corrupt people enjoy being reported publicly.

The casual behaviour perpetrators of crime display on television as they are being tried does not suggest any feelings of remorse for their doings. Some even laugh when their sentence is handed down. A rehabilitation programme based on the principles of ubuntu, facilitated by those with a character of integrity could make a difference. Such 
facilitators should be screened first. Furthermore, those appointed in municipal offices in villages should be subjected to working with ubuntu teachers (elders) to mentor them.

Schools are the second area under the spotlight. Schools can also be blamed for failing to inculcate ubuntu in children through the programmes they offer. A study conducted during the period 2004 to 2008 reveals that school children from different kinds of communities show very little respect for their school principals, parents, educators, elders and friends (Mabovula, 2011). Many of them fail to meet commitments in school work because they do not keep time and promises and they fail to do their homework (Mabovula, 2011). Mabovula (2011, p. 40) also observed that they carry knives and guns to school and in their communities. This makes parents lose a grip on raising their children according to the African worldview. Communities are now fragmented morally to a point where parents no longer share the responsibility of raising children. Parent A from family $A$ can no longer reprimand child B from family $B$ who is spotted misbehaving. Thus, child behaviour is running incongruent to the ideals of ubuntu.

The findings of another study conducted by Bohman, Vasuthevan, Van Wyk and Ekman (2007) reveal that parents who took part in the study speak about their children who are dying of AIDS and complain that the children do not want to listen to them about how to avoid the disease. One of the participants is quoted as calling on parents to put their heads together to get a way to stop this illness from killing their children. Parents are concerned about young people who do not respect their bodies and explain that they (participants) were taught to respect their bodies. They react to the circumstances where young people are exposed and encouraged to use contraceptives, which they see as an approval of an early sex debut.

The third area posing a threat to ubuntu is crime. Crime statistics has soared - killings, hijackings, rape, child molestation, et cetera. According to Mabovula (2011, p. 39), community members no longer trust each other due to lack of discipline, violence, crime and aggressive behaviour in the society. "Regardless of fluctuations in rates of incidence and categories, the erosion of traditional codes of humanism continues to create an on-going challenge to the African communities" (Mabovula, 2011, p. 39). For instance, Mabovula (2011, p. 39) states, "the emergence of a new antitraditional African phenomenon of xenophobic incidents among Africans has compounded the fast erosion of efficacy of ubuntu". These incidents are cutting through the communal ideals of ubuntu. Some occurrences of xenophobia expressed through looting are actually acts of theft disguised as a reaction by locals towards foreign nationals. People just steal other people's belongings. This challenge seems to be compounded by the absence of control and proper management of influx of foreigners into South Africa. Many of those who are allowed into the country come with evil intentions to do crime. These intentions undermine African traditional values that promote harmony and a sense of pride in the African cultural heritage (Mabovula, 2011, p. 39).

The next area that I want to discuss is communalism versus individualism. The principle of communalism which characterises African philosophy has been and continues to be eroded by western individualism. Many Africans are now looking out for themselves and are self-centred instead of upholding ubuntu by understanding themselves and all that they are trying to do through the broader community. While I do not mean that individualism means crime, I opine that individualism has a potential to breed crime because it is coated with racial connotations - self-centredness, looking out for oneself, hate of those who are of a different race, and so on. Mabovula (2011, p. 40) cites Khoza, who defines individualism as the political and social philosophy that places high value on the freedom of the individual and generally stresses the self-directed, self-contained and comparatively unrestrained individual or ego. This is directly opposed to communalism and communitarianism as defined above. People do not see others as fellow human beings but as animals to kill in order to take their belongings. Media reports indicate a surge in shootings, stabbings, rapes and robberies (Mabovula, 2011, p. 40). Mabovula (2011, p. 40) attests to individualism spoiling ubuntu, by stating:

In addition to incidences of violence, community members have now developed an individualistic philosophy, which tends to run counter to many traditional values.

In contrast to individualism, communalism resides in the ideals of ubuntu. I offer a practical illustration of communalism from a wedding function that I attended in 2013 in Venda - an individual, a bride, being welcomed into a community (extended family, other community members and friends). The performances that welcomes the ngwetsi (Tswana: bride) into the Venda family include the Venda cultural dances and rituals to express a warm welcome for the bride in the family. Stirred by my inquisition, I asked the father of the receiving family about the meaning of certain rituals that were being performed. Part of his answer explains ubuntu in terms of communalism:

We are happy that you [referring to my family] and everyone else came. Without this, the celebration would not materialise. We would not be seen to be people. We prepared what we prepared to share with every attendee because our African culture demands that we do that in the spirit of ubuntu. Without you, I am not a person because the only sense that I can make about myself is to see myself through another person. Alone, I am a dead person (Personal discussion, 2013). 
To buttress the point about communalism, I relate the findings of a study by a team of South African and Swedish science researchers from the University of Pretoria and the Blekinge Institute of Technology/Karolinska Institutet. The study was part of a bilateral cooperation project in education and research between these institutions (Bohman et al., 2007, p. 324).

The study reveals a valuable finding that relates to the concept of communalism through one participant who describes how having a meal with friends is important and how African people share. According to the participants in this cited study, not being able to share resources makes them feel bad and makes their hearts ache. This confirms the fact that individualism is in itself un-African. On the other hand the study reveals challenges that participants face in their daily lives which fragment the values of ubuntu - alcohol, drugs and concomitant crimes and violence. Safety is a big issue for them as they indicate that incidences of crime bar them from living harmoniously as a community. The participants fear the weekends when people abuse alcohol and drugs and most crimes are committed. According to them, night time is a chance for thugs to steal when power is off and they (elders) cannot even phone the police.

Furthermore, the participants think that alcohol and drugs has a severe impact on young people and are a major cause of people acting cruelly and committing brutal assaults. One of the participants talks about the fear of being raped and cited the story of an old lady in her neighbourhood who was beaten and raped in her own home and left to die. They notice that those who commit crimes are in many cases, but not always, strangers. They often talk about their fear even of the people they know. Many of them have personal experience of relatives who have been murdered. They are especially concerned when they have to receive their old age pension money at pay points where they feel vulnerable.

Based on my religious convictions, I want to dedicate the last part of this section to deepening the understanding of ubuntu by borrowing from a religious perspective. Masango (2006, p. 930) writes that the great gift that God has given to people is the gift of life. Life is lived happily in the midst of, with and in interacting with fellow human beings. For this to happen it means that one should see the other first as an image of God and as a neighbour. In this way there is a room to embrace each other by displaying the ideals of ubuntu, including respect for others, feeling a sense of responsibility towards others and accommodating each other as members of a community. Masango avers that in fact one grows up with ubuntu from early childhood, especially in rural African villages in the sense that, as people grow and relate to each other they are taught by the elderly to pass on what they learn to another person. To this let me introduce the concept of ancestor:

An ancestor is someone who has reached a great age and maturity in life, who during his or her lifetime has acquired a vast experience of life, including deep spirituality. Hence, they share their rich experiences and spiritual life with other young villagers (Masango, 2006, p. 936).

Therefore, it does not come as a surprise why Africans like to be associated with elders and/or ancestors and would thus urge their children to do the same - it is for educational purpose, that is, to draw on the endowed profundities of knowledge and wisdom. Thus, ubuntu is passed on from one generation to another. According to Masango, this is the beginning of caring about each other. Masango further explains how the notion of caring manifests itself in the respectful and humble way elders and superiors are greeted and addressed by the young.

It is not wrong to say that a human being is nothing but humanness as it is shared by many African tribes (Masango, 2006, p. 930-931). Masango goes on to claim that in an African village the image and likeness of God is revered and when one adds the concept of ubuntu one must also connect it to African spirituality which forms values and good character in a person. That is why the educational approach for an African child might be incomplete without building into it the aspects of spiritualism and holism. According to Masango, concepts of humanness are part and parcel of humanity from the beginning of the creation story. Masango relates the application of these concepts in the African context, which scholars engaged. Using an example in relating this, Masango states that Hermes (from Egypt), wrote about these concepts, and Pythagoras continued to write and develop the ideas further after he studied in Africa. For twenty-two years he studied at the University of Heliopilis under African philosophers, the Egyptian high priests, Soclits and Onuphis. Soclits and Onuphis taught Hermes about the inner values and African concepts of humanness which were given to human beings by God. Their theory was centred on the inner value and dignity of the human personality which is nothing else but "humanness" instilled in human beings (Broodryk in Masango, 2006, p. 932). Masango relates further that an African writer by the name of Koka connected the above ideas by developing the concept of respect and connecting the ideas to African spirituality. For example:

The word 'Ntate' (father) is used to address an old man or respected father figure in the village or community (Koka in Masango, 2006, p. 931). 
Man was declared "human" as soon as the element of "divine" (image) goodness (likeness) got instilled in him (Broodryk in Masango, 2006, p. 931). This divine element that transformed man into a human being was nothing but a humanness, "ubuntu" that manifested the "image and likeness" of God in each individual person of the human race (Broodryk in Masango, 2006, p. 931). The likeness or image of God existent in man relates to God's attributes including love, kindness, self-control and goodness, which uphold the ideals of ubuntu.

\section{The Missing Link of Ubuntu Seen Through Elders' Nostalgic Voices}

I conducted interviews with five elders. The duration of each interview with each participant was two to three hours. The elders are all indigenous Tswanas. These elders were selected conveniently based on their availability and distance (Farrokhi, 2012). They are members of the northern Akasia community governed by the Tshwane Municipality in Pretoria. These elders formerly stayed in the villages that border on the northern part of Akasia. They have been around Akasia for five to fifteen years. I deliberately chose elders from this area because I realised that Africans, particularly elderly Africans, who have moved to the formerly white-only areas still hold on to their cultural practices - inviting the uncles and aunts to help decide over lobola for their children, call relatives and friends to help organise celebrations, run their funerals in an African way, including rituals, et cetera. There is a tendency to research aspects of Africanness in rural areas only, when Africanness is very much prevalent around urban environments as well. Limiting research of this kind to rural environments presents a skewed reality about Africanness, as though it only exists in rural environments.

For most Blacks, relocation to areas previously owned by Whites does not mean denouncing their Africanness. The differences between Blacks who have made inroads into these areas and those who live in rural areas are only in terms of the degree of prevalence of their cultural practices; the rurally based Blacks exhibit more of these practices and the urban-based Blacks exhibit diminished practices. The explanation is simple: cultural practices of Blacks living in urban areas are restricted to a greater extent by the structural arrangements that owe their originality to western contexts. In fact, many have bought properties formerly designed and owned by westerners. The lifestyle in such areas is attuned to the western lifestyle rather than the African lifestyle. For example, the orientation is that of inward looking and focusing on one's immediate family, as opposed to Africans who have extended family ties. Similar to this is westerners' individualistic approach versus Africans' communalistic approach to life. Structural designs limit the crowd kind of arrangements by which Africans like to run their functions, evidenced in limited parking space, for instance.

The elders interviewed in 2013 were aged 55 upwards. Two of them were about to retire, two had already retired. All of them were professionals in the civil service. This profile helped with the understanding of the views of "educated" elders who still clung to their African cultural practices to some extent. (I deliberately present educated in inverted commas because the aspect of education should also be problematised. There is a tendency to look down on African elders because many of them did not go to school. School has been designed from the western perspective to portray an element of status and enlightenment. This view on schooling has closed the alternative view to understand education from an African perspective.) The choice to sample elders was important in this research to partly address the assumption that educated Africans have totally denounced their culture. I have been following these elders over a long period of time (approximately five years), noting their way (philosophy) of life. This has entailed taking field notes and observation, which helped with the understanding of the gathered data. I reserved the use of any recording device by resorting to scribing in order to maintain the African mode of communication, which is characterised by active listening and paying attention - using one's ears more, which has crucial implications for education and training, that is, to train in listening skills. Thus, the reason for this decision was to get actively involved in the discussion through note-taking and listening attentively. Some degree of attention in the discussion can be lost when one relies on recorded data, knowing that it is on tape, anyway.

For ethical reasons, I contacted these elders telephonically to secure preliminary appointments with them individually, to explain what I intended to engage them on and to get their consent. The purpose of the interviews was thus explained to them. They all showed willingness to participate in the interviews. Contacting them telephonically initially helped to plan dates for the interviews and member-checking. I assigned them the following names instead of their real names: Monnamogolo More, Mmemogolo Senwamadi, Mmemogolo Molwantwa, Mmemogolo Ditshaba, Mmemogolo Mokwena. The designators "Monnamogolo" and "Mmemogolo" refer to grandfather and grandmother respectively. These designators not only have reference to age differentiation, but more to the respect due to the elders.

Data analysis followed the tracing of common issues that were being raised across the responses to the two main questions asked: What is ubuntu? What went wrong with ubuntu? The content of the scribed data was closely studied and analysed through coding, categorisation and ultimately theme building (Boyatzis, 1998; Cohen, Manion \& Morrison, 2002). The indigenous language being used to a limited extent in the findings is Setswana, to maintain the original 
meaning of words or because there was no direct translation of such words. The elders were also allowed the liberty to express their views in Setswana where they felt they wanted to. My competence is Setswana helped with the translation and understanding of the response. The responses to the first question yielded some valuable information that provided a window into the second question about the elders' concerns. The first question was important to ask to create a sense of what the elders regarded as ubuntu. It provided the background to the concerns raised in the second question.

\subsection{Findings}

\subsubsection{What is ubuntu?}

My expectation about responses to this question was offset by the elders answering the second question before I had even asked it. So, their response to the first question actually came via their response to the second question. At times I tried to keep them focussed on the first question. However, I soon realised that they could not wait to express the urgency of their worries about the erosion of ubuntu. I further realised that botho (ubuntu) was basically viewed one-sidedly by these elders, that is, in terms of how the young relate to old people. Mmemogolo Mokwena said in this regard:

\section{Botho means to respect and honour the elderly; it is about manners and a restraint to go with an unmannered person.}

Another finding from the elders' response is that they profusely complained about the youth's behaviour. Mmemogolo Mokwena related how children are expected to relate to each other and how to conduct themselves in front of the elders, drawing from Godly principles:

We grew up in a religious way; it was wrong to hear other children swear. We even respected each other as siblings. Even in the Bible we read about the banishment of King Nebuchadnezzar because he undermined God.

This finding can be related to the fact that in African communities there are ubuntu-based norms and values by which a child is raised; therefore it becomes unexpected to see a child behaving disrespectfully. The respect expected by elders from children was detailed by Mmemogolo Senwamadi. According to her, in an African context a child is taught in the home and thus is expected to listen. In the morning the child should greet seated as a sign of respect, without waiting for the older person to greet first. A boy-child is supposed to take off his hat and kneel down (Tswana: go thaba thedi), not with a sense of stubbornness (Tswana: go gwatalala). She stated:

Holding one's hip or putting hands in the pocket in the case of boys while talking or receiving from an elderly person is disrespectful.

When a child is given something he/she is supposed to "clap" (go phaphatha) and receive with two hands put together as a symbol for being thankful. She concurred with Mmemogolo Mokwena by bringing in a Biblical perspective: "raising children does not really differ from the Bible".

It can be deduced that according to these elders the central value of ubuntu is respect for the elderly. Even though I tried my best to steer the discussion towards how ubuntu is viewed among the elderly only or how they relate to the young, these elders still clung to the idea that the young are the ones who are supposed to show respect for the elderly since they are being raised and groomed into future adults.

Only Mmemogolo Molwantwa mentioned that "parents do not project a good image in marriage in front of their children because they fight and show disrespect for each other". While I acknowledge the expectations of the elderly about children being the ones to show respect, I align myself with Mmemogolo Molwantwa's view about the role that parents must play to model ubuntu. The meaning of her name (Molwantwa - "one who fights the fight") tunes in well with her fighting for the parents to resume their proper parental position. It is disconcerting to watch unbecoming behaviour being projected by older people whom children should look up to for good behaviour. At times one gets very disappointed to hear vulgar language coming from them. It is also disappointing to see older men going out with young girls the age of their own girl-children. This is a disgusting behaviour which spoils ubuntu.

There is perhaps no better way to refer to older men who show this disgusting behaviour than using the Setswana expression: Go ija mothana (meaning that it is like "sleeping" with one's own girl-child). It is also unspeakable when one hears true stories of fathers who sexually abuse their own daughters! How the older generation conducts itself has an impact on the extent to which the young are taught ubuntu. 
Following the elders' responses I now close this sub-section by stating that it seems that the interviewed elders can only explain ubuntu by placing the child in the centre. According to them, ubuntu is all about children behaving according to how the elders and/or parents have raised them from a frame of reference of respect due to the elders, behaving well, and so on.

The next sub-section looks at the question, "What happened to ubuntu?"

\title{
5.1.2 What happened to ubuntu?
}

The analysis of the concerns raised in the elders' views concentrated on certain patterns or themes according to which I decided to present the findings:

\subsubsection{Organisation and leadership}

Africans are known to organise themselves to give service to their fellow community members. This is very much evident especially during functions like weddings. However, the elders expressed a concern that this important value of ubuntu seemed to be fading away. Mmemogolo Senwamadi related her observation about a funeral in a village some kilometres to the northwest of Pretoria, called Tholwe where she was impressed by how "men organised themselves, went to gather wood and built setlhatha (set/hatha is a temporary shelter made from tree branches where cooking is done). She also related another incidence that she observed at a funeral at Dikweipi, a village in the area of Rustenburg:

\begin{abstract}
Men organise themselves and prepare and are responsible for cooking the meat called masugu which they will eat; they are not supposed to eat kidneys as these are for the old women who cannot give birth anymore. So, the women also have their pots organised and prepare the entrails to feed those who arrive on the evening of the funeral. (Masugu refers to a part of a cow's meat that consists of tendons and ligaments.)
\end{abstract}

The interviewees alluded to the fact that protocol is observed with each person playing their role just like the uncle and aunt are key figures during the weddings and funerals of their nephews and nieces. It would be much appreciated if every government programme introduced in communities could have as part of its goals, ways to promote and work together with the existing community structures which promote the practice of ubuntu. The unfortunate thing is the introduction of political figures who seem to take over from chiefs as the whole community now diverts the attention from elders to these politicians in the hope of being better looked after. While the commitment by government is to provide services to communities, care should be taken not to raise political figures above community leaders. A proper partnership between the tribal government system and the state-based government system has a potential to recognise the tribal authorities' contribution in upholding the ideals of ubuntu, which can mitigate crime. The richness of knowledge and wisdom in the elders/ancestors cannot be shunned if we are to see good governance. Hence, as Masango (2006) puts much credit to the educational role that elders/ancestors play, government officials and everyone that aspires to a leadership position, should not excommunicate themselves from the elders/ancestors.

\subsubsection{The principle of Batho pele in the provision of services}

The elders expressed their disappointment at paying lip service to the principle of Batho pele when it comes to the provision of services, especially in government institutions. "At the post office, for example, you may be left unattended; the workers seem not to care at all about you" (Mmemogolo Mokwena). Monnamogolo More said that in hospital the behaviour of the medical staff, particularly that of the nursing staff, is questionable: "They talk and shout at you as if you are no human being, and some of them are far younger than you". Indeed, I agree that the Batho pele principle is being compromised to a larger extent. It is terribly ironical that in institutions like hospitals and police stations one is greeted by Batho pele principles displayed on the notice boards which are not practised at all.

At most service points the first impression one gets is that the receptionists are not welcoming, which can be seen as disinterest in the client. One is allowed to enter and then realise that whoever is supposed to help one drags his/her feet. In institutions like banks the setting up of multiple service points is a response to the rising demand for service from clients. However, at times one gets frustrated because the queues are long, yet only two staff members are available even though it is not yet time for a lunch break. Perhaps a behind-the scenes review should be conducted to ensure that staff members are at their posts. But, if ubuntu is emphasised (Masango, 2006) and it forms part of institutional training 
for different careers, the Batho pele principles can be seen in operation.

\subsubsection{Parental role}

Though raised by one elder in 5.1.1, this theme was expected given the complaint of elders about the disrespectfulness of children towards older people. "Families have given up on upholding morals" (Mmemogolo Ditshaba). "Children are given away to toys to raise them up" (Monnamogolo More). Job demands seem to have exacerbated this problem because the standard of living causes both the father and mother to go to work. Children are taken to a crèche from a tender age and as a result parent-child bonding is diminished. Moreover, many of the crèches that children are taken to are owned by Whites. No discussion is entered into about the programme that the crèche should offer in relation to what parents desire for their children; only how much the services are. This situation places the child under "parental guidance" that does not promote African norms and values.

The situation regarding the crèche can also be observed in schools. Many of the schools that Africans take their children to are former Model $\mathrm{C}$ schools which still have white dominance and culture. For eight hours of the day these children are exposed to the European way of life that comes through the curriculum that they receive in class and the hidden curriculum that perpetrates the European culture. For example, in many schools children are not allowed to converse in their home or indigenous language on the school campus even during lunch breaks. They ultimately get coerced or assimilated into the European culture and develop a sense of disvaluing their cultures which ends up being labelled as primitive, backward and inferior.

This state of affairs creates an undesirable disjuncture between the home culture and the school culture, which in turn creates a state of confusion in children, especially when they enter secondary school education and realise that they cannot identify with the curriculum that is offered to them. They then convert to violent behaviour as is partly attested to by Mabovula's (2011) study.

\subsubsection{Influence of media and technology}

The elders blame the media and technology for changing the lives of young people for the worse. The elders' views acknowledged their own ignorance to some extent regarding their understanding of cellphone technology. Monnamogolo More stated in this regard:

Long before you know it, they do things through what the cell phone can offer which are difficult for you to understand; as it is said, they chat, twitter and facebook with everyone in the world, even with the people that they do not know.

According to Mmemogolo Mokwena, this is the reason why children live secretive lives which parents do not know about and it breeds stubbornness in them; they refuse to be sent around when they are needed to do things for their parents and grandparents; "but we know that soon their lives will be destroyed because the cellphone has given them new and fast legs to reach dangerous places in the social circles, like night clubs, wild parties, et cetera." (Mmemogolo Mokwena). This is because children are not close to the elders in whom Masango (2006) sees the value of education, but they are closer to technological gadgets which they abuse. From a religious point of view, the interviewees attributed the bad influence of the media and technology to the evil spirit that is ravaging society at large. Children can no longer focus on their school work because they feed on the television drama and actors whom they emulate as their role models even though their lives are in shambles. They watch pornography downloaded from the internet via their cellphones.

\subsubsection{Substance abuse and crime}

Ubuntu is being spoiled by abuse of substances like drugs and liquor. It becomes clear from the views of the elders that they are worried about their safety as a result of substance abuse; "drugs make boys to be out of their senses and rape even old women" (Mmemogolo Senwamadi); "rape cases that we hear about on the news are very scary; they rape and kill you mercilessly" (Mmemogolo Ditshaba). Mmemogolo Ditshaba further expressed her frustrations and concerns about security:

Ubuntu is gone as a result of crime and drug abuse; we do not own our lives anymore. From receiving our money at the end of the month, even our nieces and nephews either steal or take it by force from us. Where is ubuntu in this?

The elders blamed adults for selling drugs and liquor to young people. They called on the government to police 
these acts. Illicit sex creeps in when people are under the influence of drugs and liquor and this adds to the HIVIAIDS statistics (see the cited study of Bohman et al, 2007 in section 4 above). Children are also influenced by the violent behaviour in their social circle and are lured into all sorts of crime as communities lure or force them into these violent acts, some of which are related by Mabovula (2011). Some communities force a shutdown of and/or burn schools.

\subsubsection{Non-observance of religious principles}

The interviewed elders were religiously inclined. Thus, this became a considered theme as they kept relating the concept of ubuntu to the Biblical principles: "Ubuntu originates from the Word of God because we are told about loving and respecting your neighbour or fellow man as you love yourself" (Mmemogolo Senwamadi). "From a Biblical point of view, children are supposed to respect and to honour their parents so they can receive a blessing to live longer" (Monnamogolo More). This finding confirms Masango's (2006) views about ubuntu as related in section 4 above. Masango advances a view that ubuntu is about humanism which owes its nature to God. This implies that humans should emulate God in as far as living harmoniously with each other. However, elders lament the fact that people wander far away from their Creator and as a result they do all sorts of evil. According to the views expressed, children who participate in church activities like a weekend away at a youth camp to be taught God's Word generally show good moral behaviour.

\subsubsection{Sharing and helping each other}

Today's society does not share as used to be the practice of ubuntu among African communities. This view was expressed by Mmemogolo Senwamadi when she related how it used to be:

It was well known amongst Africans who kept livestock that if they knew their neighbours were poor, they asked a neighbour's child to shepherd their flock and this ensured the child would bring back home milk or meat. Old men stored planks to make coffins. When someone dropped dead he/she would be kept only for a day. Sand was collected into a room, wetted and the corpse laid on it to remain cool until burial. The coffin would be ready by the next morning and a funeral would thus take place.

Mmemogolo Senwamadi's response attests to communalism which should be promoted to ensure caring for one another as opposed to individualism, the two concepts that Mabovula (2011) contrasts.

\section{Conclusion}

In this paper I have raised and deliberated on the issues that surround ubuntu. It is clear from the elders interviewed that ubuntu has to do with raising the young in a manner that is respectful so that they know how to carry themselves in relation to the elders. The elders raised serious concerns about the current behaviour in the society that spoils the beauty of ubuntu, thus having an impact on the work of raising children according to the values encapsulated in ubuntu. This behaviour surfaces in leadership and children. Based on the findings of the study reported in this paper, I want to suggest an ubuntu mode of living that will ensure the restoration of an ubuntu ethos. This mode is illustrated in figure 1. It is a mode that makes ubuntu a guide for good living. Its orientation to individualism is that of perceiving yourself as part of a collective in a community, thus deriving meaning for living from the community. In such a mode of living members of the community coexist by collaborating with each other. A community living according to this mode cherishes the wealth of wisdom that emanates from the elders. Such a community will guide leadership by involving elders. Such a community will infuse the ideals of ubuntu as part of education and training for its children. Thus, the education of children will be designed in such a way that it promotes African values that are based on ubuntu. 
Figure 1: Ubuntu mode of living

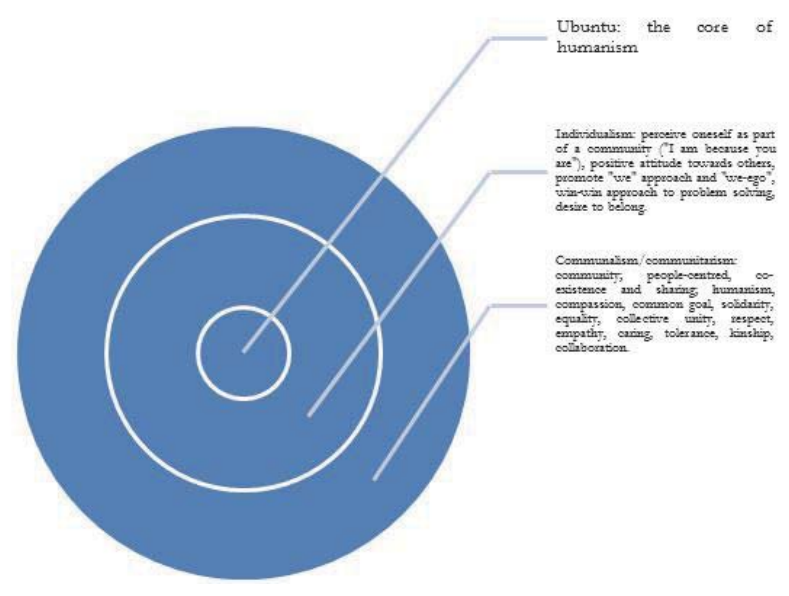

The mode figured above is opposed to the individualism mode in figure 2. The individualism mode places a high premium on an individual person. It is opposed to communalism as illustrated through arrows pointing in opposite directions in figure 2. This mode has a potential to cause divisions in the community and is an enemy of ubuntu.
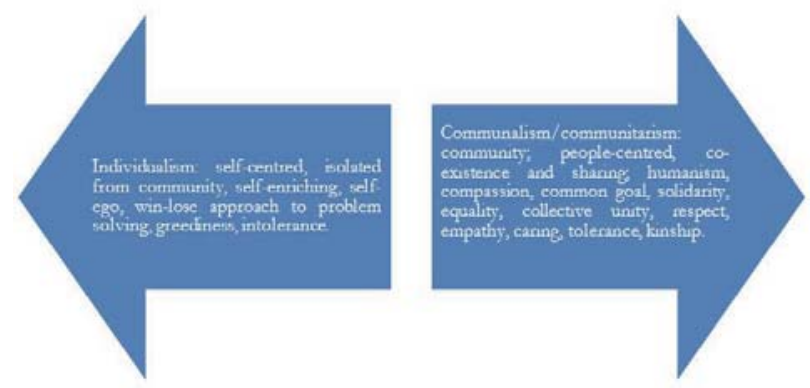

Figure 2: Individualism mode

\section{References}

Bohman, D. M. \& Vasuthevan, S., Van Wyk, N. C. \& Ekman, S. (2007). We clean our houses, prepare for weddings and go to funerals: Daily lives of elderly Africans in Majaneng, South Africa. J Cross Cult Gerontol, 22, 323-337. DOI 10.1007/s10823-007- 9040-8.

Boyatzis, R. E. (1998). Transforming qualitative information: Thematic code analysis and code development. Thousand Oaks: SAGE.

Broodryk, J. (2006). Ubuntu: African life coping skills - Theory and practice. CCEAM Conference. Lefkosia, Cyprus.

Cohen, L., Manion, L. \& Morrison, K. 2002. Research methods in education (5th ed). London: Routledge Falmer.

Farrokhi, F. (2012). Rethinking convenience sampling: Defining quality criteria. Theory and Practice in Language Studies, 2(4), 784-792.

Khoza, R. J. (2005). Let Africa lead. Sunninghill: Vezubuntu.

Mabovula, N. N. (2011). The erosion of African communal values: A reappraisal of the African ubuntu philosophy. Inkanyiso, Journal of Human \& Social Sciences, 3(1), 38-47.

Masango M. J. S. (2006). African spirituality that shapes the concept of ubuntu. Verbum Et Ecclesia Jrg, 27(3), 930-943.

Mokgoro, J. Y. (1997). Ubuntu and the law in South Africa. Paper presented at Colloquium Constitution and Law. Potchefstroom, South Africa.

Muwanga-Zake, J. W. F. (2009). Building bridges across knowledge systems: Ubuntu and participative research paradigms in Bantu communities. Discourse: Studies in the Cultural Politics of Education, 30(4), 413-426.

Nassbaum, B. (2003). Ubuntu: Reflections of a South African on our common humanity. Reflections, 4(4), 21-26.

Nyaumwe, L. J. \& Mkabela, Q. (2007). Revisiting the traditional African cultural framework of ubuntuism: A theoretical perspective. Indilinga - African Journal of Indigenous Knowledge Systems, 6(2), 152-163.

Personal Discussion during wedding celebration in Venda (2013).

Ramose, M. B. (2002). The philosophy of ubuntu and ubuntu as a philosophy: In Coetzee, P. H. \& Roux, A. P. J. Philosophy from Africa: A text with readings 2nd Edition. Cape Town: Oxford University Press. 